There remains one golden key, capable of unlocking the whole apparently puzzling problem, and its name is co-operation. On this recently-settled continent (more especially being so largely of Anglo-Saxon stock), we are not as. yet awake to the fact that forest-born blessings and benefits are of vastly greater public value and far-reaching significance, than are the more or less doubtful profits reaped by a licensed exploiter. But happily we are beginning to waken up. Witness the deeply-significent fact that since Mr. Roosevelt took office, over 90 per cent of the money spent along forestry lines in the big. republic has been public money, although over 90 per cent of the timber being cut came from private lands! Here in the Land of the Maple forestry progress must continue in the doldrums until the great Public become forest. conscious enough to realize their overwhelming measure of responsibility for proper forest management, and provide funds accordingly. Some strange idiosyncracy seems to prevent our applying the providential function of Government to safeguard the future of this most important resource. Sweden shows us the way - whole-hearted, commonsense co-operation.

J. R. Dickson.

\title{
MARTIN ALLERDALE GRAINGER 1874-1941
}

Martin Allerdaie Grainger died in his office in Vancouver, of a heart attack, on October 15, at the age of 67. For more than thirty years he had been a leading figure in the lumber industry of British Columbia.

For the five years from 1915 to 1920 Martin Grainger served as Provincial Forester of British Columbia, leaving the Government Service to enter the industrial field. In 1922 he organized the AlberniPacific Lumber Company for British financial interests and he acted as managing director of the company until 1935 . The company operated a mill at Port Alberni and had a number of large logging operations along the Coast.

At the time of his death he was managing the Forest Investments Company, a British syndicate dealing in timber lands.

A former member of the Canadian Society of Forest Engineers, Mr. Grainger was president of that body for the years 1921, 1922 and 1923. He is survived by his widow. 